\title{
"PASTI OKE" \\ BUDAYA KERJA ISLAMI BRISYARIAH DAN PENGARUHNYA \\ PADA KINERJA KARYAWAN \\ (Studi Kasus pada BRIsyariah Kantor Cabang Banyuwangi)
}

\author{
Nurul Inayah \\ ninailzam2015@gmail.com \\ Institut Agama Islam Darussalam Blokagung Banyuwangi
}

\begin{abstract}
The purpose of this study was to see the effect of the Islamic culture of "Definitely Okay" on the performance of Bank BRISyariah employees at the Banyuwangi branch office, with a quantitative descriptive approach. With the determination of census samples totaling 28 employees. Data collection techniques with observation techniques, interview techniques, questionnaire techniques or questionnaires and documentation techniques. While the research instrument used in this study was a questionnaire. Test instruments used are validity and reliability, data transformation using excel programs, while the data analysis tool used is multiple regression, the results of the study show that the Islamic culture of "Definitely Okay" has a positive effect on Employee Performance.
\end{abstract}

Keywords: Islamic work culture, definitely okay, employee performance, Islamic banking

\section{PENDAHULUAN}

Bank BRI sebagai salah satu Bank terbesar milik pemerintah yang sudah ada sejak 16 Desember 1895, sejalan dengan perjalanan waktu yang menuntut segala sendi kehidupan berubah, PT. Bank Rakyat Indonesia (Persero)Tbk., telah melakukan pengembangan dengan melakukan akuisisinya, terhadap Bank Jasa Arta pada 19 Desember 2007 dan setelah mendapatkan izin dari Bank Indonesia pada 16 Oktober 2008 melaluisuratnya o.10/67/KEP.GBI/DpG/2008, maka pada tanggal 17 November 2008 PT. Bank BRISyariah secara resmi beroperasi. Kemudian PT. Bank BRISyariah merubah kegiatan usaha yang semula beroperasional secara konvensional, kemudian diubah menjadi kegiatan perbankan berdasarkan prinsip syariah Islam.

Menjadi PT. Bank BRISyariah yang berprinsip syariah islam maka budaya perusahaan melakukan penyesuian dengan layanan finansial sesuai 
$270\}$ ㅅ "Pasti Oke" Budaya Kerja Islami BRISyariah dan Pengaruhnya

kebutuhan nasabah dengan jangkauan termudah untuk kehidupan lebih bermakna. Melayani nasabah dengan pelayanan prima (service excellence) dan menawarkan beragam produk yang sesuai harapan nasabah dengan prinsip syariah.

Penyesuaian dengan perubahan harus dilakukan, untuk itu PT. Bank BRISyariah yang berprinsip syariah islammembangun budaya organisasi sebagai upaya membangun identitas perusahaan. Suatu perusahaan atau organisasi perlu untuk membentuk kultur atau budaya yang mampu menjadi identitas perusahaan serta acuan dalam bertindak dan berperilaku. Dengan adanya budaya kerja atau organisasi, karyawanakan merasa bangga dengan perusahaan serta memiliki acuan dalam bekerja. Budaya organisasi yang kuat akan membuat perusahaan dalam memberikan kepastian kepada seluruh karyawan untuk berkembang bersama, tumbuh dan berkembangnya perusahaan. ${ }^{1}$

Dengan motto "Bersama Wujudkan Harapan Bersama"perusahaan Bank BRISyariah Kantor Cabang Banyuwangiterus mempertahankan budaya perusahaan yang diterjemahkan dengan Nilai-nilai dalam 7 Budaya Kerja Islami karyawan Bank BRISyariah Kantor Cabang Banyuwangi tercantum dalam kata "PASTI OKE” yaitu:1). Profesional. 2). Antusias, 3). Sumber Daya Manusia yang berkualitas, 4). Tawakal, 5). Integtritas, 6). BerOrientasi Bisnis, dan 7). Kepuasan Pelanggan.

Untuk itu bagaimana budaya kerja islami yang telah terbentuk memberi pengaruh pada kinerja karyawan Bank BRISyariah kantor cabang Banyuwangi

\section{TINJAUAN TEORI}

\section{Budaya dan Kinerja Karyawan}

Dalam menjamin kelangsungan hidup organisasi dalam lingkungan yang kompetitif, suatu organisasi harus mampu melakukan perubahan dengan memiliki kemampuan untuk beradaptasi dengan sistem yang baru juga dengan budaya yang baru.Teori modern mengemukakan bahwa organisasi bukanlah suatu sistem tertutup yang berkaitan dengan lingkungan yang stabil, tetapi organisasi adalah suatu sistem terbuka yang harus menyesuaikan diri dengan perubahan-

\footnotetext{
${ }^{1}$ Stephen P. Robbins, Prinsip-prinsip Perilaku Organisasi, diterjemahkan oleh Halida dan Dewi Sartika, (Jakarta: Erlangga, 2002), hlm. 281.
}

..::: Malia: Jurnal Ekonomi Islam, Volume 10 Nomor 2 Juni 2019 :::.. 
perubahan lingkungannya. Konsep-konsep yang berkaitan dengan budaya organisasi dengan kecocokan orang-organisasi adalah penting bagi keberhasilan organisasi, dan sebagai upaya peningkatan kinerja organisasi.

Menurut Schein, budaya organisasi adalah pola dasar yang diterima oleh organisasi untuk bertindak dan memecahkan masalah, membentuk karyawan yang mampu beradaptasi dengan lingkungan dan mempersatukan anggota-anggota organisasi. ${ }^{2}$ Robbins (1996:289), budaya organisasi adalah suatu persepsi bersama yang dianut oleh anggota-anggota organisasi itu.Wood, Wallace, Zeffane, Schermerhorn, Hunt, Osborn, budaya organisasi adalah sistem yang dipercayai dan nilai yang dikembangkan oleh organisasi dimana hal itu menuntun perilaku dari anggota organisasi itu sendiri. ${ }^{3}$ Mowat budaya organisasi adalah "the personality of the organization: the shared beliefs, values and behaviours of the group. It is symbolic, holistic, and unifying, stable, and difficult to change."Robbins pengertian budaya organisasi adalah sistem makna bersama yang dianut oleh anggota-anggota yang membedakan suatu organisasi dari organisasi lain. Sistem makna bersama ini, bila diamati dengan lebih seksama, merupakan seperangkat karakteristik utama yang dihargai oleh suatu organisasi. Budaya organisasi berkaitan dengan bagaimana karyawan mempersepsikan karakteristik dari suatu budaya organisasi, bukan dengan apakah para karyawan menyukai budaya atau tidak. Schein dalam Ivancevich et.al., mendefinisikan budaya sebagai suatu pola dari asumsi dasar yang diciptakan, ditemukan, atau dikembangkan oleh kelompok tertentu saat belajar menghadapi masalah adaptasi eksternal dan integrasi internal yang telah berjalan cukup baik untuk dianggap valid, dan oleh karena itu, untuk diajarkan kepada anggota baru sebagai cara yang benar untuk berpersepsi, berpikir dan berperasaan sehubungan dengan masalah yang dihadapinya. ${ }^{4}$

Budaya organisasi adalah nilai-nilai yang dianut oleh anggota organisasi dan dijalankan dan mempengaruhi kinerja. Hofstede et al.,

\footnotetext{
${ }^{2}$ Edy Sutrisno, Budaya Organisasi, (Jakarta: Kencana, 2010), hlm. 6

${ }^{3}$ Putra, Sujudi Ragil, Pengaruh Motivasi Kerja, Lingkungan Kerja dan Pengawasan Kerja Terhadap Produktivitas Kerja Karyawan Pada BMT Bina Ihsanul Fitri Yogyakarta, Skripsi, Prodi Ekonomi UII Yogyakarta, 2006.

${ }^{4}$ Algifari. Statistika Induktif untuk Ekonomi dan Bisnis. Yogyakarta: UPP AMP YKPN. 2003.
}

..::: Malia: Jurnal Ekonomi Islam, Volume 10 Nomor 2 Juni 2019 :::.. 
$272\}$ “Pasti Oke" Budaya Kerja Islami BRISyariah dan Pengaruhnya

dalam penelitiannya yang berjudul "Individual perception of organizational cultures: A methodological treatise on level of analysis, dimana pada hasil penelitian tersebut adalah Budaya organisasi berpengaruh positif terhadap komitmen organisasional dan berdampak pada kinerja karyawan. ${ }^{5}$

Kinerja karyawan Menurut Anwar Prabu Mangkunegara dalam Ningrum, Sunuharyo, dan Hakam istilah kinerja berasal dari kata job performanceatau actual performance (prestasi kerjaatau prestasi sesungguhnya yang dicapai seseorang). Pengertian kinerja (prestasi kerja) adalah hasil kerja secara kualitas dan kuantitas yang dicapai seorang karyawan dalam melaksanakan tugasnya sesuai dengan tanggung jawab yang diberikan kepadanya. Kinerja (perfomance) mengacu kepada kadar pencapaian tugas-tugas yang memebentuk sebuah pekerjaan karyawan. Penilaian kinerja adalah proses dimana organisasi mengawasi pelaksanaan kerja individu. Dalam penilaian kinerja dinilai kontribusi karyawan kepada organisasi selama periode tertentu. Umpan balik penilaian kinerja memungkinkan karyawan mengetahui seberapa baik mereka bekerja jika dibandingkan dengan standar organisasi. ${ }^{6}$

Sedangkan menurut Bernadine:1998, Ada 6 (enam) kriteria penting kinerja yaitu:

a. Kualitas (Quality)

Adalah hal yang menunjukkan proses atau hasil dari penyelesaian suatu kegiatan yang mendekati sempurna dan memenuhi tujuan kegiatan.

b. Kuantitas (Quantity)

Sejumlah hasil atau keluaran yang dinyatakan dalam nilai satuan, jumlah unit atau jumlah kegiatan.

c. Ketepatan waktu (Timeliness)

Adalah berapa lama waktu yang dibutuhkan untuk menyelesaikan pekerjaan atau suatu keluaran dapat dihasilkan pada

\footnotetext{
${ }^{5}$ Tri Cahyono, Bambang,Manajemen Sumber Daya Manusia, Jakarta: BADAN PENERBIT IPWI, 1996Ujang Sumarwan, Perilaku konsumen . Teori dan penerapannya dalam Pemasaran, (Jakarta: Ghalia Indonesia, 2003), 170.

6 Zama ${ }^{\text {ee }}$ Syari, Muhammad,Pengaruh Etos Kerja dan Budaya Kerja Islam Terhadap Produktivitas Kerja Kayawan (Studi penelitian KJKS/UJKS Wilayah Kabupaten Pati),Skripsi,Prodi Ekonomi Islam IAIN Walisongo Semarang,2011.
} 
awal waktu yang diinginkan, serta memaksimalkan waktu untuk kegiatan lain.

d. Efektivitas biaya (Cost Effectiveness)

Adalah hal yang menunjukkan penggunaan sumber daya organisasi seperti manusia, dana, tehnologi dan material secara maksimal untuk mendapatkan keuntungan yang sebesar-besarnya.

e. Kebutuhan akan Supervisi (Need for Supervision)

Suatu aktifitas pengawasan terhadap karyawan bagaimana mereka dapat menjalankan fungsi pekerjaan.

f. Pengaruh hubungan personal (Interpersonal Impact)

Mengembangkan rasa penghargaan diri, berbuat baik dan bekerja sama dengan sesama pekerja maupun dengan atasan. Gibsons, menyebutkan bahwa faktor yang mempengaruhi perilaku dan kinerja dibedakan menjdi 3 variabel yaitu: ${ }^{7}$

1) Variabel individu yaitu kemampuan dan ketrampilan (mental dan fisik), latar belakang (pengalaman, keluarga dst.) dan demografis (umur, asal usul, dll.).

2) Variabel Organisasi yaitu sumber daya, kepemimpinan, imbalan (kompensasi), struktur organisasi dan diskripsi pekerjaan (job description).

3) Variabel Psikologis yaitu persepsi, sikap, kepribadian, pola belajar dan motivasi.

\section{Budaya Kerja Islami Di Bank BRISyariah Kantor Cabang Banyuwangi}

Dalam meningkatkan kinerja adalah tentang bagaimana cara menerapkan budaya kerja Islami. Budaya kerja adalah suatu falsafah yang didasari oleh pandangan hidup sebagai nilai-nilai yang menjadi sifat, kebiasaan dan kekuatan pendorong, membudaya dalam kehidupan suatu kelompok masyarakat atauorganisasi, kemudian tercemin dari sikap menjadi perilaku, kepercayaan, cita-cita, pendapat dan tindakan yang terwujud sebagai "kerja" atau "bekerja". 8 Melaksanakan budaya kerja tidak bisa dipisahkan dengan sumber daya manusia (SDM) itu sendiri,

\footnotetext{
${ }^{7}$ Deliarnov, Perkembangan Pemikiran Ekonomi, Jakarta: Raja Grafindo Persada,1997.

8 Mangkunegara, Anwar Prabu (2001) dalam Ningrum, Sunuharyo, dan Hakam (2013) "Pengaruh Pendidikan dan Pelatihan Terhadap Kinerja Karyawan", Jurnal Administrasi Bisnis (JAB) 6:1-8.
} 
274 \} “Pasti Oke" Budaya Kerja Islami BRISyariah dan Pengaruhnya

karena budaya kerja sangat erat kaitannya dengan sikap atau perilaku dan paradigma berpikir manusia dalam menciptakan kinerja yang memadai.

Budaya kerja Islam haruslah bermotivasikan, dinamisme dan memupuk sifat dinamik untuk memimpin. Pekerja akan menyadari potensi dan kekuatan yang dikaruniakan Allah kepadanya seperti daya cipta, akal, pemikiran asli, bakat yang tersendiri, kemampuan menggunakan alat-alat tertentu dan sebagainya. Itulah yang dinamakan budaya bekerja dalam perspektif Islam. Kerja pada hakekatnya adalah manifestasi amal kebajikan. Sebagai sebuah amal, maka niat dalam menjalankannya akan menentukan penilaian. Dalam sebuah hadits, Nabi Muhammad bersabda, "Sesungguhnya nilai amal itu ditentukan oleh niatnya".

Budaya kerja yang diterapkan di institusi syariah adalah "SIFAT" yang merupakan singkatan dari Siddiq, Isiqomah, Fatanah, Amanah, dan Tablig. ${ }^{9}$ Dimana penjabaran sifat-sifat tersebut sebagi berikut :

a. Siddiq

Berarti memiliki kejujuran dan selalu melandasi ucapan, keyakinan, serta perbuatan berdasarkan ajaran Islam. Tidak ada kontradiksi dan pertentangan yang disengaja antara ucapan dan perbuatan. Oleh karena itu, Allah memerintahkan orang-orang yang beriman untuk senantiasa memiliki sifat Siddiq dan menciptakan lingkungan yang siddiq.

b. Istiqomah

Istiqomah, artinya konsisten dalam iman dan nilai-nilai yang baik meskipun menghadapi berbagai godaan dan tantangan. Isiqomah dalam kebaikan ditampilkan dengan keteguhan, kesabaran, serta keuletan, sehingga menghasilkan sesuatu yang optimal. Istiqomah merupakan hasil dari suatu proses yang dilakukan secara terus - menerus. Misalnya, interaksi yang kuat dengan Allah dalam bentuk shalat, zikir, membaca Al-Qur'an, dan lain-lain. Semua proses itu akan menumbuh kembangkan suatu sistem yang memungkinkan kebaikan, kejujuran, dan keterbukaan teraplikasi dengan baik.

${ }^{9}$ Algifari. Statistika Induktif untuk Ekonomi dan Bisnis. Yogyakarta: UPP AMP YKPN. 2003.

..:::: Malia: Jurnal Ekonomi Islam, Volume 10 Nomor 2 Juni 2019 :::... 
c. Fathanah

Berarti mengerti, memahami, dan menghayati secara mendalam segala hal yang menjadi tugas dan kewajiban. Sifat ini akan menumbuhkan kreativitas dan kemampuan untuk melakukan berbagai macam inovasi yang bermanfaat. Kreatif dan inovatif hanya mungkin dimiliki ketika seorang selalu berusaha untuk menambah berbagai ilmu pengetahuan, peraturan, dan informasi, baik yang berhubungan dengan pekerjaannya maupun perusahaan secara umum.

d. Amanah

Berarti memiliki tanggung jawab dalam melaksanakan setiap tugas dan kewajiban. Amanah ditampilkan dalam keterbukaan, kejujuran, pelayanan yang optimal, dan ihsan (berbuat yang terbaik) dalam segala hal. Sifat amanah harus dimiliki oleh setiap mukmin, apalagi yang memiliki pekerjaan yang berhubungan dengan pelayanan bagi masyarakat.

e. Tablig

Berarti mengajak sekaligus memberikan contoh kepada pihak lain untuk melaksanakan ketentuan-ketentuan ajaran Islam dalam kehidupan kita sehari-hari. Tablig yang disampaikan dengan hikmah, sabar, argumentatif, dan persuasif akan menumbuhkan hubungan kemanusiaan yang semakin solid dan kuat.

Kemudian dalam budaya organisasinya juga sama, budaya kerja dalam organisasi yang Islami juga diterapkan dalam lembaga keuangan syari'ah seperti di Bank BRISyariah Kantor Cabang Banyuwangi. Seperti inisiatif individu adalah tingkat tanggung jawab,kebebasan, dan kemandirian yang dimiliki individu karyawan; toleransi terhadap resiko memberikan gambaran tingkat pengambilan risiko, inovasi, dan keberanian individu karyawan.

Untuk mencapai sasaran utama, yang ditetapkan adalah meningkatkan efisiensi dan kinerja karyawan dalam menjalankan kegiatan usaha dengan terus mempertahankan budaya perusahaan Bank BRISyariah Kantor Cabang Banyuwangi. Adapun pernyataan nilai-nilai budaya kerja islami dari Bank BRISyariah yaitu, sikap dan perilaku karyawan PT. BRISyariah Kantor Cabang Banyuwangi, dengan motto "Bersama Wujudkan Harapan Bersama". Nilai-nilai dalam 7 Budaya Kerja karyawan Bank BRISyariah Kantor Cabang Banyuwangi tercantum dalam kata "PASTI OKE" yaitu: 
276 \} “Pasti Oke" Budaya Kerja Islami BRISyariah dan Pengaruhnya

a. Profesional yaitu kesungguhan dalam melakukan tugas sesuai dengan standar teknis dan etika yang telah di tentukan.

b. Antusias yaitu semangat dan dorongan untuk berperan aktif dan mendalam pada setiap aktvitas kerja.

c. Sumber Daya Manusia yang berkualitas serta memperlakukan baik sebagai individu maupun kelompok berdasarkan saling percaya, terbuka, adil, dan menghargai, yaitu menempatkan dan menghargai karyawan sebagai modal utama perusahaan dengan menjalankan upaya-upaya yang optimal mulai dari perencanaan, perekrutan, pengembangan dan pemberdayaan.

d. Tawakal yaitu optimisme yang di awali dengan doa yang sungguhsungguh di manifestasikan dengan upaya yang sungguh-sungguh dan diakhiri dengan keikhlasan atas hasil yang dicapai.

e. Integtritas yaitu kesesuaian antara kata dan perbuatan dalam menerapkan etika kerja, nilai-nilai, kebijakan dan peraturan organisasi secara konsisten sehingga dapat di percaya dan senantiasa memegang teguh etikaprofesi dan bisnis meskipun dalam keadaan yang sulit untuk melakukannya.

f. BerOrientasi Bisnis yaitu tanggap terhadap perubahan dan peluang, selalu berfikir dan berbuat untuk menghasilkan nilai tambah dalam pekerjaannya.

g. Kepuasan Pelanggan yaitu Memiliki kesadaran sikap serta tindakan yang bertujuan memuaskan pelanggan eksternal dan internal di lingkungan perusahaan.

Selain itu, Bank BRISyariah juga memiliki kebijakan manajemen. Kebijakan yang telah ditetapkan adalah mengembangkan dunia usaha secara umum, khususnya usaha kecil menengah dan koperasi, dengan berpedoman kepada prinsip kepatuhan, kehati-hatian, good coorporate governance, dan komitmen dari seluruh pengurus dan karyawan.

\section{DISAIN PENELITIAN}

Penelitian ini menggunakan pendekatan kuantitatif deskriptif, dengan menggunakan analisis regresiberganda. Populasi dan sekaligus sampel dengan menggunakan teknik sensus sampling dari penelitian ini adalah staff dari Bank BRISyariah Kantor Cabang Banyuwangi yang berjumlah 28 orang, yang terdiri dari 27 orang staff dan 1 orang pimpinan. Teknik 
pengambilan data dengan Teknik Observasi, Teknik Wawancara, Teknik Angket atau Kuisioner dan Teknik Dokumentasi. Sedangkan instrumen penelitian yang digunakan dalam penelitian ini adalah kuisioner (angket) dimana para responden mengisi angket dengan memberi tanda cheklist $(\sqrt{ })$ pada jawaban yang sesuai. Setiap butir pertanyaan dalam kuesioner (angket) disediakan 4 kategori. Setiap jawaban dinyatakan dengan SS (sangat setuju) dengan score $=4$, huruf $S$ (setuju) dengan score $=3$, TS (tidak setuju) dengan score $=2$, STS (sangat tidak setuju) dengan score $=1$.Uji instrument yang digunakan yaitu uji validitas dan reliabilitas, transformasi data menggunakan program excel, sedangkan alat analisis data yang digunakan adalah regresi berganda, dengan nilai koefisien determinan korelasi berganda.

\section{UJI VALIDASI DAN REABILITAS INSTRUMEN Instrumen variabel Budaya Kerja Islami}

Untuk menguji validasi instrumen menggunakan korelasi dengan rumus pearson product moment sebagai berikut:

$$
\mathrm{r}_{\text {hitung }}=\frac{N\left(\sum X Y\right)-\{(\Sigma X)(\Sigma Y)\}}{\sqrt{\left(N \cdot \sum X^{2}-(\Sigma X)^{2}\right\}\left[N \sum Y^{2}-(\Sigma !\right.}}
$$

maka dari perhitungan dihasilkan dalam bentuk tabel sevagai berikut :

Jika $t_{\text {hitung }}>t_{\text {tabel }}$ berarti valid dan $t_{\text {hitung }}<t_{\text {tabel }}$ berarti tidak valid

\begin{tabular}{|l|l|l|l|l|}
\hline $\begin{array}{l}\text { No. } \\
\text { Item }\end{array}$ & $\begin{array}{l}\text { koefisien } \\
\text { korelasi } \mathrm{r}_{\text {hitung }}\end{array}$ & $\begin{array}{l}\text { Harga } \\
\mathrm{t}_{\text {hitung }}\end{array}$ & $\begin{array}{l}\text { Harga } \\
\mathrm{t}_{\text {tabel }}\end{array}$ & Keputusan \\
\hline 1 & 0,446 & 2,541 & 2,056 & Valid \\
\hline 2 & 0,522 & 3,121 & 2,056 & Valid \\
\hline 3 & 0,399 & 2,219 & 2,056 & Valid \\
\hline 4 & 0,468 & 2,700 & 2,056 & Valid \\
\hline 5 & 0,464 & 2,671 & 2,056 & Valid \\
\hline 6 & 0,432 & 2,442 & 2,056 & Valid \\
\hline 7 & 0,393 & 2,179 & 2,056 & Valid \\
\hline
\end{tabular}

\section{Instrumen variabel Kinerja Karyawan}

Untuk menguji validasi instrumen menggunakan korelasi dengan rumus pearson product moment sebagai berikut:

$$
\mathrm{r}_{\text {hitung }}=\frac{N\left(\sum X Y\right)-\{(\Sigma X)(\Sigma Y)\}}{\sqrt{\left[N \cdot \Sigma X^{2}-(\Sigma X)^{2}\right]\left[N \Sigma Y^{2}-(\Sigma !\right.}}
$$


278 \} “Pasti Oke" Budaya Kerja Islami BRISyariah dan Pengaruhnya

maka dari perhitungan dihasilkan dalam bentuk tabel sevagai berikut :

Jika $t_{\text {hitung }}>t_{\text {tabel }}$ berarti valid dan $t_{\text {hitung }}<t_{\text {tabel }}$ berarti tidak valid

\begin{tabular}{|l|l|l|l|l|}
\hline $\begin{array}{l}\text { No. } \\
\text { Item }\end{array}$ & $\begin{array}{l}\text { koefisien korelasi } \\
\mathrm{r}_{\text {hitung }}\end{array}$ & $\begin{array}{l}\text { Harga } \\
\mathrm{t}_{\text {hitung }}\end{array}$ & $\begin{array}{l}\text { Harga } \\
\mathrm{t}_{\text {tabel }}\end{array}$ & Keputusan \\
\hline 1 & 0,561 & 3,456 & 2,056 & Valid \\
\hline 2 & 0,526 & 3,154 & 2,056 & Valid \\
\hline 3 & 0,422 & 2,373 & 2,056 & Valid \\
\hline 4 & 0,399 & 2,219 & 2,056 & Valid \\
\hline 5 & 0,551 & 3,367 & 2,056 & Valid \\
\hline 6 & 0,426 & 2,401 & 2,056 & Valid \\
\hline 7 & 0,536 & 3,237 & 2,056 & Valid \\
\hline
\end{tabular}

Selanjutnya instrumen diuji kembali dengan reabilitas Instrumen penelitian yang reliabilitasnya diuji dengan test-retest dilakukan dengan cara mencobakan instrumen beberapa kali pada responden (Sugiyono, 2006:274). Setelah diperoleh harga $r_{1}$ hitung, selanjutnya untuk dapat diputuskan instrumen tersebut reliabel atau tidak, harga tersebut dikonsultasikan dengan harga $r_{\text {tabel. }}$. Dengan $n=28$ taraf kesalahan 5\% diperoleh 0,374. Karena $r_{1}$ hitung lebih besar dari $r_{\text {tabel }}$ untuk tarif kesalahan $5 \%(0,675$ 0,374) maka dapat disimpulkan instrumen kemampuan kerja tersebut reliabel dan dapat dipergunakan untuk penelitian.

\section{HASIL PENELITIAN}

\section{Hasil Analisis Data}

Penelitian yang dilaksanakan di PT. Bank BRISyariah Kantor Cabang Banyuwangi menggunakan metode kuantitatif. Dengan melibatkan sebanyak 28 responden, memberikan informasi mengenai bagaimana pengaruh budaya kerja terhadap kinerja karyawan, dari judul penelitian ini pengaruh masing-masing variabel independen budaya kerja (X) dan variabel dependen kinerja karyawan (Y) dapat dijelaskan sebagai berikut:

\section{a. Pengaruh Budaya Kerja Terhadap Kinerja Karyawan}

Dalam perhitungan valid dan reliabel,data dianalisis dengan menggunakan uji F. Fhitung sebesar 10,462 kemudian membandingkan dengan Ftabel sebesar 3,38. Dengan membandingkan Fhitung dengan Ftabel maka, mempunyai pengaruh yang signifikan 
antara pengaruh pengawasan dan budaya kerja islami terhadap kinerja karyawan. Untuk menentukan besarnya pengaruh secara parsial terdapat pengaruh pengawasan, dan budaya kerja $\mathrm{Rx} \_1$ x_2 =0,591 besarnya pengaruh $\mathrm{kp}=\mathrm{R}^{\wedge}(2)=0,6752=45,59 \%$, sedangkan pengaruh budaya kerja islami terhadap kinerja keryawan $\mathrm{Rx} \_2 \mathrm{y}=$ 0,531 besarnya pengaruh $\mathrm{kp}=\mathrm{R}^{\wedge}(2)=0,5312=28,20 \%$.

Maka dalam hasil uji empiris pengaruh antara budaya kerja islami terhadap kinerja karyawan menunjukkan nilai besarnya pengaruh

terdapat

pengaruh antara budaya kerja islami dengan kinerja karyawan $R x_{2} y=$ 0,531 besarnya pengaruh $\mathrm{kp}=R^{2} \quad 0,5312=28,20 \%$.

yang artinya semakin besar budaya kerja maka semakin besar kinerja karyawan.

Dari analisis data menunjukkan bahwa koefisien regresi untuk variabel adalah signifikan dengan tingkat signifikan 0,000 atau 5\%. Hal ini menunjukkan bahwa variabel budaya kerja islami memberi pengaruh yang signifikan terhadap kinerja karyawan.

\section{b. Uraian Instrumen variabel Budaya Kerja Islami (X)}

1) Melakukan tugas sesuai dengan standar teknis dan etika yang telah di tentukan $=3,088$

2) Semangat untuk berperan aktif dan mendalam pada setiap aktvitas kerja $=2,408$

3) Berperilaku baik sebagai individu dengan saling percaya, terbuka, adil, dan menghargai, yaitu menempatkan dan menghargai karyawan sebagai modal utama perusahaan $=3,183$

4) Tawakal/Optomisme dengan upaya yang bersungguh-sungguh atas hasil yang dicapai $=2,671$

5) konsisten sehingga dapat di percaya dan senantiasa memegang teguh etika profesi dan bisnis meskipun dalam keadaan yang sulit untuk melakukannya $=3,864$

6) Tanggap dengan adanya peluang, dengan berfikir, dan berbuat untuk untuk menghasilkan nilai tambah dalam pekerjaannya.= 2,367

7) Kesadaran sikap untuk memuaskan pelanggan eksternal dan internal di lingkungan perusahaan. $=5,012$ 
$280\}$ “Pasti Oke" Budaya Kerja Islami BRISyariah dan Pengaruhnya

Dari uraian pengaruh variabel budaya kerja islami terhadap kinerja karyawan, diketahui bahwa indikator Kesadaran sikap untuk memuaskan pelanggan eksternal dan internal di lingkungan perusahaan memiliki pengaruh terbesar dengan nilai $=5,012$ dan indikator Tanggap dengan adanya peluang, dengan berfikir, dan berbuat untuk untuk menghasilkan nilai tambah dalam pekerjaannya merupakan indikator terkecil yang mempengaruhi kinerja karyawan yaitu $=2,367$.

\section{PEMBAHASAN}

\section{Budaya Kerja Pada Bank BRISyariah}

Menurut Robbins budaya organisasi adalah sistem makna bersama yang dianut oleh anggota-anggota yang membedakan suatu organisasi dari organisasi lain. Sistem makna bersama ini, bila diamati dengan lebih seksama, merupakan seperangkat karakteristik utama yang dihargai oleh suatu organisasi. Budaya organisasi berkaitan dengan bagaimana karyawan mempersepsikan karakteristik dari suatu budaya organisasi, bukan dengan apakah para karyawan menyukai budaya atau tidak. Misalnya situasi lingkungan bisnis yang menuntut adanya adaptasi dan perubahan organisasi, namun di sisi lain budaya organisasi menginginkan tidak adanya perubahan dan mempertahankan status quo, maka organisasi akan mengalami inertia yang pada akhirnya dapat mengalami kemunduran.

Saat iniOrganisasi yang memiliki tradisi, dan cara umum yangberhasil dalam melakukan sesuatuyang besar karena apa yang telah dilakukan sebelumnya dan sukses dalam melakukannya hal tersebutmaka semestinya mampu membawa kita ke sumber utama dari budaya organisasi: yaitu pendirinya dan motivasi pendirian dari organisasi tersebut.

Pendirian Bank BRISyariah yang berasal dari peleburan antara PT. Bank Rakyat Indonesia (Persero), Tbk.,dengan Bank Jasa Arta pada 19 Desember 2007, telah membuat perubahan dan penyesuainya. Dan PT. Bank BRISyariah merubah kegiatan usaha yang semula beroperasional secara konvensional, kemudian diubah menjadi kegiatan perbankan berdasarkan prinsip syariah Islam.

Perubahan yang harus dilakukan sesuai dengan Schein dalam Ivancevich et.al., mendefinisikan budaya sebagai suatu pola dari asumsi 
dasar yang diciptakan, ditemukan, atau dikembangkan oleh kelompok tertentu saat belajar menghadapi masalah adaptasi eksternal dan integrasi internal yang telah berjalan cukup baik untuk dianggap valid, dan oleh karena itu, untuk diajarkan kepada anggota baru sebagai cara yang benar untuk berpersepsi, berpikir dan berperasaan sehubungan dengan masalah yang dihadapinya. ${ }^{10}$ Dengan melakukan proses pembentukan budaya yang baru dengan mengadopsi nilai-nilai islam dan Budaya kerja yang diterapkan di institusi syariah adalah "SIFAT" yang merupakan singkatan dari Siddiq, Isiqomah, Fatanah, Amanah, dan Tablig. ${ }^{11}$ Dimana sifat-sifat tersebut pada akhirnya di adopsi dan diterjemahkan dalam budaya kerja yang ada di Bank BRISyariah dengan Nilai-nilai dalam 7 Budaya Kerja karyawan Bank BRISyariah Kantor Cabang Banyuwangi tercantum dalam kata "PASTI OKE".Dan sifat-sifat tersebut dapat dijabarkan sebagai berikut :

a. Siddiq, berarti memiliki kejujuran dan selalu melandasi ucapan, keyakinan, serta perbuatan berdasarkan ajaran Islam. Sifat siddiq dimuncul dalam Integtritas yaitu kesesuaian antara kata dan perbuatan dalam menerapkan etika kerja, nilai-nilai, kebijakan dan peraturan organisasi secara konsisten sehingga dapat di percaya dan senantiasa memegang teguh etikaprofesi dan bisnis meskipun dalam keadaan yang sulit untuk melakukannya.

b. Istiqomah, artinya konsisten dalam iman dan nilai-nilai yang baik meskipun menghadapi berbagai godaan dan tantangan. Sedangkan sifat istiqomah di leburkan dalam budaya kerja yang Profesional yaitu kesungguhan dalam melakukan tugas sesuai dengan standar teknis dan etika yang telah di tentukan. Dansekaligus Antusias yaitu semangat dan dorongan untuk berperan aktif dan mendalami pada setiap aktvitas kerja.

c. Fathanah, berarti mengerti, memahami, dan menghayati secara mendalam segala hal yang menjadi tugas dan kewajiban. BerOrientasi Bisnis yaitu tanggap terhadap perubahan dan peluang, selalu berfikir dan berbuat untuk menghasilkan nilai tambah dalam pekerjaannya.

10 Deliarnov, Perkembangan Pemikiran Ekonomi, Jakarta: Raja Grafindo Persada, 1997. 432

${ }^{11}$ Edy Sutrisno, Budaya Organisasi, (Jakarta: Kencana, 2010), hlm. 6

..::: Malia: Jurnal Ekonomi Islam, Volume 10 Nomor 2 Juni 2019 :::... 
$282\}$ “Pasti Oke" Budaya Kerja Islami BRISyariah dan Pengaruhnya

d. Amanah, berarti memiliki tanggung jawab dalam melaksanakan setiap tugas dan kewajiban.Sifat amanah ini lebih pada pendalaman tanggung jawab pada pelayanan akan kepuasan pelanggan, Kepuasan Pelanggan yaitu Memiliki kesadaran sikap serta tindakan yang bertujuan memuaskan pelanggan eksternal dan internal di lingkungan perusahaan.dan pelayanan pada kepuasan pelanggan diharuskan juga memiliki Integtritas

e. Tablig, berarti mengajak sekaligus memberikan contoh kepada pihak lain untuk melaksanakan ketentuan-ketentuan ajaran Islam dalam kehidupan kita sehari-hari. Tablig yang disampaikan dengan hikmah, sabar, argumentatif, dan persuasif akan menumbuhkan hubungan kemanusiaan yang semakin solid dan kuat. Dan Sifat Tabliq ini dicerminkan pada budaya kerja pada Sumber Daya Manusia yang berkualitas serta memperlakukan baik sebagai individu maupun kelompok berdasarkan saling percaya, terbuka, adil, dan menghargai, yaitu menempatkan dan menghargai karyawan sebagai modal utama perusahaan dengan menjalankan upaya-upaya yang optimal mulai dari perencanaan, perekrutan, pengembangan dan pemberdayaan.

\section{Pengaruh Budaya Kerja Terhadap Kinerja Karyawan}

Budaya organisasi mempunyai dampaksignifikan pada prestasi kerja ekonomi perusaha-an dalam jangka panjang. Hasil penelitianHarvard Bussiness School Kotter dan Heskett menunjukkan bahwa budaya perusahaanmempunyai dampak yang kuat dan semakinbesar pada prestasi kerja organisasi. M.H. Beyer dalam disertasinya di Delaware Universitymenyebutkan bahwa kepustakaan yang ada saatini sudah cukup mendukung asumsi bahwabudaya yang kuat mengarah pada kinerja yanglebih tinggi, sehingga yang lebih penting lagiadalah melakukan telaah lebih lanjut lagi. JosephC. Wilson seorang eksekutif kepala perusahaan Xerox Corp. Memimpin perusahaan tersebut,dimana dia seorang yang agresif dan memilikijiwa wirausaha, maka perusahaan tersebutmengalami kemajuan yang besar dengan basismesin fotokopi jenis 914, sebagai salah satuproduk yang berhasil di USA. Di bawahkepemimpinannya Xerox mendapatkanlingkungan usaha yang memiliki budaya informal,bersahabat, inovatif, dan berani menanggung resiko. Dan penelitian ini juga mendukung bahwa budaya kerja mempengaruhi kinerja karyawan.

..::: Malia: Jurnal Ekonomi Islam, Volume 10 Nomor 2 Juni 2019 :::... 
Budaya kerja pada penelitian ini lebih fokus pada budaya kerja islami yang mengadopsi nilai-nilai islam terutama pada nilai siddiq, istiqomah, fathonah, amanah, dan tablig, yang selanjutnya melebur pada nilai-nilai dalam 7 budaya kerja karyawan Bank BRISyariah Kantor Cabang Banyuwangi tercantum dalam kata “PASTI OKE" yaitu:1). Profesional. 2). Antusias, 3). Sumber Daya Manusia yang berkualitas, 4). Tawakal, 5). Integtritas, 6). BerOrientasi Bisnis, dan 7). Kepuasan Pelanggan.

Dari hasil penelitian didapatkan bahwa : indikator melakukan tugas sesuai dengan standar teknis dan etika yang telah di tentukan memberikan pengaruh pada kinerja sebesar $=3,088$. Kemudian pada indikator semangat untuk berperan aktif dan mendalam pada setiap aktvitas kerjamemberikan pengaruh sebesar $=2,408$. Pada indikator Berperilaku baik sebagai individu dengan saling percaya, terbuka, adil, dan menghargai, yaitu menempatkan dan menghargai karyawan sebagai modal utama perusahaan memberi pengaruh sebesar $=3,183$. Sedangkan indikator Tawakal/Optomisme dengan upaya yang bersungguh-sungguh atas hasil yang dicapai mempengaruhi sebesar = 2,671. Pada indikator konsisten sehingga dapat di percaya dan senantiasa memegang teguh etika profesi dan bisnis meskipun dalam keadaan yang sulit untuk melakukannya memberi pengaruh sebesar $=3,864$. Pada indikator tanggap dengan adanya peluang, dengan berfikir, dan berbuat untuk untuk menghasilkan nilai tambah dalam pekerjaannya memberi pengaruh sebesar $=2,367$. Dan ternyata Kesadaran sikap untuk memuaskan pelanggan eksternal dan internal di lingkungan perusahaanmemberikan pengaruh terbesar dengan memberikan kontribusi sebebar.= 5,012. Artinya para karyawan yang berada di lingkungan Bank BRISyariah kantor cabang Banyuwangi sudah sangat memahami pekerjaannya sebagai pegawai perbankan yang harus siap melayani nasabah setiap saat.

Dan pada indikator Tanggap dengan adanya peluang, dengan berfikir, dan berbuat untuk untuk menghasilkan nilai tambah dalam pekerjaannya merupakan indikator terkecil yang mempengaruhi kinerja karyawan yaitu $=2,367$. Artinya karyawan Bank BRISyariah kantor cabang Banyuwangi kurang kreatif untuk menghasilkan nilai tambah dalam pekerjaannya. 
$284\}$ “Pasti Oke" Budaya Kerja Islami BRISyariah dan Pengaruhnya

\section{KESIMPULAN}

Hasil penelitian menunjukkan bahwa budaya kerja islami yang ada di Bank BRISyariah kantor cabang Banyuwangi berpengaruh terhadap kinerja karyawan. Dimana pada budaya kerja islami di poin tentang kesadaran sikap untuk memuaskan pelanggan eksternal dan internal memberikan kontribusi paling besar yaitu 5,012. Penterjamahan nilai-nilai islam telah dileburkan pada : a.Sifat Siddiq, ditermahkan dalam budaya Integtritas, b. Sedangkan sifat istiqomah di leburkan dalam budaya kerja yang Profesional, c.Sifat Fathanah, ditermahkan pada budaya BerOrientasi Bisnis. Sedangkan sifat Amanah, berarti memiliki tanggung jawab dalam melaksanakan setiap tugas dan kewajiban. d. Sifat amanah ini lebih pada pendalaman tanggung jawab pada pelayanan akanKepuasan Pelanggan, dan e. Sifat Tabliq ini dicerminkan pada budaya kerja pada Sumber Daya Manusia yang berkualitas.

\section{DAFTAR PUSTAKA}

Ahlami, Budaya Kerja Menurut Persepektif Islam, diambil dari http://haslizaali.blogspot.com/2009/12/budaya-kerja-menurut-

persepektif-islam.htmlAward BRI Syari'ah,http://visimisibrisyariah.co.id/?q=awards, diakses tanggal 1 Juli 2017.

Algifari. Statistika Induktif untuk Ekonomi dan Bisnis. Yogyakarta: UPP AMP YKPN. 2003.

Arikunto, Suharsimi. Prosedur Penelitian: Suatu pendekatan Praktek.Jakarta: Rineka Cipta. 2002.

Brosur Edaran dan jobdiscription PT. Bank BRISyariah Kantor Cabang Banyuwangi.

Deliarnov, Perkembangan Pemikiran Ekonomi, Jakarta: Raja Grafindo Persada, 1997.

Desky, Harjoni, Pengaruh Etos Kerja Islami Dan Gaya Kepemimpinan Terhadap Kinerja Karyawan Rumah Makan Ayam Lepaas Lhokseumawe Inferensi, Jurnal Penelitian Sosial Keagamaan Vol. 8, No. 2, Desember 2014

Edy Sutrisno, Budaya Organisasi, (Jakarta: Kencana, 2010), hlm. 6 Hakim, Lukman, Membangun Budaya Organisasi Unggul Sebagai Upaya Peningkatkan Kinerja Karyawan Di Era Kompetitif, Benefit Jurnal Manajemen Dan Bisnis, (2011)

Hasan, Iqbal, Pokok-pokok Materi Statistik, Jakarta: Bumi Aksara, 2003. 
http//edisi03.blogspot.com/2008/kjks-dan-ujks.html. Diposkan oleh KPRI KIPAS.http://fathulwahid.staff.uii.ac.id/2007/10/04/membangunbuda yakerjaislami/:membangunbudaya kerja islami oleh fathul wahid. http://www.profilebrisyariah.com/2015/05/.htmldiakses pada 1 Juli 2017 http://www.puskopsyahlampung.com//perkembangan-bri-dari-tahunketahun.htmldiakses

Kholidah,Dedeh,Pengaruh Motivasi Terhadap Peningkatan Prestasi Kerja Karyawan Pada PT BPRS Amanah Ummah Bogor, Skripsi, Prodi Ekonomi UII Yogyakarta, 2006.

Mangkunegara, Anwar Prabu (2001) dalam Ningrum, Sunuharyo, dan Hakam (2013) "Pengaruh Pendidikan dan Pelatihan Terhadap Kinerja Karyawan", Jurnal Administrasi Bisnis (JAB) 6:1-8

Mc. Clelland, D., et al., The Achievement Motive, (New York : AppletonCentury-Crofts,1953) dalam Abdul Hamid Mursi, SDM yang Produktif: Pendekatan Al-Qur'an...,h.116

Pajar, "Analisis Faktor-faktor yang mempengaruhi produktivitas kerja karyawan bagian keperawata pada Rumah Sakit PKU Muhammadiyah Surakarta", Jurnal Skripsi Fakultas Ekonomi UMS, 2008.

Putra, Sujudi Ragil, Pengaruh Motivasi Kerja, Lingkungan Kerja dan Pengawasan Kerja Terhadap Produktivitas Kerja Karyawan Pada BMT Bina Ihsanul Fitri Yogyakarta, Skripsi, Prodi Ekonomi UII Yogyakarta, 2006.

Riduwan, Metode \& Teknik Menyusun Tesis, Bandung : Penerbit Alfabeta, 2004.

Sejarah BRI Syari'ah, http://brisyariah.co.id/?q=sejarah, diakses tanggal 2 Juli 2017.

Stephen P. Robbins, Prinsip-prinsip Perilaku Organisasi, diterjemahkan oleh Halida dan Dewi Sartika, (Jakarta: Erlangga, 2002), hlm. 281.

Sugiyono, Metode Penilitian Kuantitatif Kualitatif dan R\&D, Bandung : Penerbit Alfabeta, 2008

Sugiyono, Statistika Untuk Penelitian, Bandung : Penerbit Alfabeta, 2006.

Tri Cahyono, Bambang,Manajemen Sumber Daya Manusia, Jakarta: BADAN PENERBIT IPWI, 1996Ujang Sumarwan, Perilaku konsumen . Teori dan penerapannya dalam Pemasaran, (Jakarta: Ghalia Indonesia, 2003), 170. 
286 \} "Pasti Oke" Budaya Kerja Islami BRISyariah dan Pengaruhnya

Zama" Syari, Muhammad,Pengaruh Etos Kerja dan Budaya Kerja Islam Terhadap Produktivitas Kerja Kayawan (Studi penelitian KJKS/UJKS Wilayah Kabupaten Pati),Skripsi,Prodi Ekonomi Islam IAIN Walisongo Semarang, 2011. 